\title{
Does Malala Need Saving? Understanding Western Idea of Rescue and Importance of Islamic Feminism in Malala Yousafzai's Autobiography
}

\author{
Shabnur Parveen
}

Department of English, Visva- Bharati, West Bengal, India

Received: 19 Nov 2021; Received in revised form: 11 Dec 2021; Accepted: 20 Dec 2021; Available online: 31 Dec 2021 (C)2021 The Author(s). Published by Infogain Publication. This is an open access article under the CC BY license (https://creativecommons.org/licenses/by/4.0/).

\begin{abstract}
My paper entitled "Does Malala Need Saving? Understanding Western Idea of Rescue and Importance of Islamic Feminism in Malala's Yousafzai's Autobiography" endeavours to understand a very specific focus to trace the problematic identity of Muslim women in any South-Asian Muslim society and try to project how an individual Muslim woman locates herself in the male-dominated Muslim society. The purpose of this research is to argue how women are oppressed and humiliated in the name of religion. Here Malala is reacting against the falsity of society by writing their life narratives. The protagonists are believers of Islam and they are not speaking against Islam and the Quran, rather they are raising their voice against how the patriarchal society is misrepresenting the Quranic verses and using them against the women of the society. On the other side, whenever the women of Third World country are divulging their story, the West is immediately taking the responsibility to promote Muslim women's position in the Muslim world, as a victim. Hence they are suffering from double oppression. On one hand, they are condemned by their society for raising voice against existing norms of the society, and on the other hand, they fall under the tendency of the West to represent the backwardness of the Muslim country. So, in this paper, I have tried to highlight the journey of the writer, how they are fighting against these oppressions and creating their own individual identity.
\end{abstract}

Keywords—Empowerment, Islamic Feminism, Third World Women, Western Media.

\section{INTRODUCTION}

"I don't want to be thought of as 'the girl who was shot by the Taliban' but 'the girl who fought for education'. This is the cause to which I want to devote my life."

(Yousafzai, 2013)

Muslim women were long improvised of freedom of choice both by the West and in their own society. Malala not only faces discrimination in the West based on her faith, dress and socio-cultural position but she also meets isolation, physical, mental abuse in her homeland. Nobody acknowledged that she can also become a model of empowerment and hope for women across the world that was previously deprived of education. Malala stood for the betterment of her countrymen but her nation accused her of being an opportunist for the comfort of the West and the Taliban mentioned her as an agent of the West.

\section{METHODS}

This paper endeavours to understand very specific but important question on the rise and history of Islamic Feminism, shooting of Malala, her treatment in the UK and the presentation of media regarding the whole incident. Then this paper will focus on Malala's treatment in the UK and the media coverage on this issue. This portion will help us to understand how the narrative of media is shaping the story of Malala and justifying their intervention in Third World country politics. How she is transformed from a strong activist of women rights and 
education to a "little Malala" by the narrative of the media (Walters, 2016). The moments when Malala resists strongly, the media never highlighted those. In this portion, I shall reflect on the popular newspaper articles and interviews to strengthen my supposition. It will show how media can be a dangerous weapon to create false discourses. Then the final part of this chapter will discuss Malala as an individual. This will show how she is not only rejecting the patriarchal model of the religion of the Taliban but also the vulnerability of Third World women created by Western media.

\section{WHAT IS ISLAMIC FEMINISM?}

The Muslim world has always been suspected by the Western notion of feminism concerning the position and condition of women in Muslim societies. Many critics argued 'Islam' and 'Feminism'-these two words are oxymoronic (Badran, 2013). The Quranic verses have been interpreted and advertised by fundamentalist patriarchal viewpoints for ages. Islam is a practice that has been developed systematically and coherently over the last 1400 years (Wadud, 1999). It has contradicted many generations, cultures, society and people. With time the interpretation of this holy text has also changed its shape. Thus this contradiction also brought conflict in the perception and understanding of the holy words. The term 'Islamic Feminism' is very much problematic. Scholars often associate it with the preaching, revelation, morals and ethics that are assigned for women. In the pre-Islamic age, women were a tool to fulfil the needs of the males of the society. Therefore, slavery and violence were the only destiny for women. Then prophet Muhammad (Peace be Upon Him) as a messenger of Islam brought a new generation, whose ultimate motive was equality, brotherhood and peace to all irrespective of gender, class, colour, creed and nationality. Hence, the popularity of this new religion was inevitable.

In 1920, historically the term 'Feminism' was used for the first time. The term Islamic Feminism comes to a global context in 1990s. This new discourse of feminism has a strong root regarding the socio-cultural viewpoint of Iran. The government rise with various kinds of unrest and chains of events with uncertainties during 1979-1990. In 1979, Iran's monarchy was replaced by the Islamic republic. In this new democracy, the monarchy was dissolved mainly by the leftist revolution. But when the Islamic republic came into power, they marginalized this leftist viewpoint and brought Islamic rules compulsory for everyone, and veiling women was one of these new rules. The notable Iranian scholars were Afsanah Najmabadeh and Ziba Mir-Hosseini. In Saudi Arabia, scholar Mai
Yamini used the term Islamic Feminism in a 1996 book named Feminism and Islam. By the middle of the 1990s in Turkey and South Africa, the idea of Islamic Feminism was growing importantly across the world. The 1990s were the years when Islamic Feminism as a critical theory began to take place in the writings of female fiction. There are three phases of Islamic Feminism. The first phase consists of the literary fiction writing by various female authors in Islamic countries. The Second phase marks the existence of Islamic Feminism in the form of social activism. The Third phase deals with the theorising and debating of the discourse and its agenda. Though these three categories are estimated through the Egyptian concept it is also much time relevant to the present world. In the first phase, Muslim feminist activists show how Muslim women are being victimized by patriarchal societies in the name of Allah. Influences of these phases in Iran were very deep. Bibi Khanum (1858-1921), a notable Iranian writer can be identified with the first rise of feminism. She wrote Muslim men should learn from Western men how to treat wives. This approach is also against intersectional feminist subjectivity. Qurrat al'Ayn (1818-1852) was another notable activist in 19th century Iran. She was arrested and killed for rejecting the veil. She was the first women martyr. Her rejection of the veil symbolizes the rejection of Islamic rule in 1852. In the second phase and third phase, Tuba Azmudeh (18781936), Mariam Behruzi (1945), Sadiqa Daulatabadi (18811961) and Mehrangiz Kar (1944), were activists voice against women suffering. They agreed and stand with women emancipation seeking equal rights not only in the private sphere but also in the public sphere. In 1979, Iran's prime minister's wife reinterprets the emancipation of Iranian women within the scriptures of true Islam. She promoted education for women and supported veiling as a code of modesty not only for women but for also men.

In Egypt, Malik Hisni Nasif Nabawiyya Musa rejected the veil and criticized British Ministry. Huda Sharawi, in 1923, established EFU (Egypt Feminist Movement). The followers of women's rights activism was Saiza Nabarawi (was from the left-wing). In 1996, Zeinab al- Ghazali, an activist of women's rights, brought an evolutionary change in the history of Islamic Feminism. In contrary to Malik Hisni Nasif Nabawiyya Musa, she promoted feminism within Islam and thought mother and wife is the primary role of women. Zeinab rejected Huda Sharawi's EFU and said the Western notion of feminism is harmful to Muslim women and Islamic roots. Nawal el Shaadawi (1931-2021) was an EFU supporter, who talked about physical exploitation of Arab Women, forceful prostitution; STD. Nawal was compared with Simon De Beauvoir. Islamic Feminists kept themselves within the Islamic Contextual 
discourse. Aminah al Said (1914-1995), a member of EFU promoted the government's education policy for both men and women. Durriyah Shafiq was a former member of EFU, known as the daughter of the Nile. She fought for the right of voting for women and went on hunger strike against the government. There are several criticisms against EFU. Bourgeoisie Organisation followed Western Feminism and was confined only within elite society. In Turkey the relevant scholars are Halide Edip and Nuket Sirman.

Islamic Feminism is a new discourse to counter Western view towards Muslim women. One of the key reasons behind this popularity is that Islamic Feminism liberates Muslim women within the parameters of Islamic rules. Margot Badran classifies two different feminisms in the Middle East, one is Secular Feminism and another is Islamic Feminism. Badran argues that Secular feminism and Islamic Feminism approached women's liberation differently. Secular feminism insists upon the implementation of gender equality in the public sphere while acquiescing in the notion of gender complementarily in the private sphere or the domain of the family. By contrast, Islamic Feminism burst on the global scene as a new discourse or interpretation of Islam and gender grounded in ijtihad (Ijtihad is an Islamic legal term referring to independent reasoning or the thorough exertion of a jurist's mental faculty in finding a solution to a legal question or independence intellectual investigation of the Quran and other religious texts. Its concern has not been simply a religious and societal reform but a fundamental transformation reflecting the practice of an egalitarian Islam. (Badran, 2013)

\section{MALALA YOUSAFZAI AND WESTERN MEDIA NARRATIVES}

Malala Yousafzai's autobiography was published in 2013 and immediately caught the attention of millions across the world. It is an astounding story of fifteen years old girl from the Swat valley of Pakistan. This is a remarkable tale of a girl who fought for education and believed education can change the world. Malala starts her autobiography with her happy childhood days in her hometown in the lush Swat Valley in North-West Pakistan. She describes the day to day life of Pushtun people before Taliban intervention. On 5th May 2009 Malala, her family and many people left the valley in fear of the Taliban. After 3 months they come back to the valley. Now the second phase of the Taliban started. In this phase, they targeted those people and killed them. Ziauddin Yousafzai and his Kushal School were constantly under threat. During one conversation Malala said, this is a very situation happening that this time Taliban are coming for only those who speak against them (Yousafzai, 2013). Much threat was on Ziauddin Yousafzai but the attack happened on Malala. On 9th October 2012 two Taliban step on the school bus and asked "Who is Malala?" One girl looked at Malala nervously. Taliban shot on her head (Yousafzai, 2013).

Malala's shooting devastated the political image of the whole country. Miraculously she survived. She had gone through multiple surgeries. Immediately after the shooting, she was rushed to hospital in the Swat Valley. After preliminary examination, Doctor advised to shift Malala to the Military hospital of Peshwar. There she was examined by Dr Junaid. Reports showed that the bullet was near the brain. Dr Junaid took a drastic step, he removed Malala's skull and put it into her stomach so that the brain could expand and saved her life. Though Malala was now out of danger the poor aftercare of the surgery was affecting her health. So, she was transferred to Birmingham Hospital, UK and her treatment continued there. This part of Malala's story is important because, despite getting lifesaving treatment in the Military hospital of Peshwar, Pakistan, no western media tried to cover that story. Rosie Walter, a famous critic of Malala Yousafzai and Pakistani women Activists researched 223 British newspapers that covered the story of Malala. She narrates that while the Pakistani hospitals involved in treating Yousafzai was named just 10 times in all those papers, but the Queen Elizabeth Hospital of Birmingham, where she was treated in the UK is named some 179 times. (Walters, 2016) Malala's autobiography narrates that this hospital has treated many wounded soldiers of Afghanistan. So here the mention of the UK's experience with gunshot patients explicitly presents its superiority over Pakistani Military Hospital. But in reality, Pakistani doctors may have much more experience than British doctors because Pakistan is dealing with war and distress since it has born.

In contemporary times, Media is the most influential source to shape the views and perception of the world. Media constructs their narrative upon various facts. The media has played a vital role in creating shared stereotypes regarding Muslim women and Muslim countries. Malala's story is framed through the West/Islam binary. UK media projected England as a safe and caring place for Malala. Despite her courageous position as a world activist, media labelled her as 'shot by Taliban' than a survivor or a feminist (Walter, 2016). These media texts endeavoured to project that the West is more liberal to Malala than her homeland. In this way, they are gaining the position of power that they are giving freedom to Malala, who was just sacrificing her life for the freedom of choice. Many postcolonial feminist critics have observed this attitude of Britain as "White men are saving brown women from 
brown men" or "The Western saviour complex" (Spivak, 2003), (Huffpost, 2013). Walter further argued the media coverage regarding Malala's willingness and bravery to speak against injustices were much underwhelming than her helplessness as a Third World woman. "She is tagged as a 'victim' (as in 'Taliban shooting victim', 'Taliban gun victim' or even 'victim girl') 35 times, and 28 times the participle 'shot' precedes her name labelled as 'shot girl/shot schoolgirl/shot Malala/shot Pakistani girl'. In contrast, despite surviving as a warrior, her name is linked with survival five times and called a 'Taliban shooting survivor' only once." (Walter, 2016) These narratives of media created two binary groups one is good and another is evil. Taliban is extreme evil and Malala is a naive 'little girl'. So to save little Malala from these monsters, Western intervention is the only way. According to the survey of Walter in nearly 140,000 words which covered the story about Malala Yousafzai, but her position as a campaigner for girls' and women's rights, is used just twice (once in The Telegraph and once in The Independent); and surprisingly, the issue of her activism came only about the UK, not about Malala. This narrative not only presents feminism as inherently a western issue but also the inability of third world women to understand the gravity of it. (Walter, 2016) The Taliban are served as extremely bad Muslims, who attacked a school girl merely for asking for education. Western media coverage focused solely upon Malala but no one made an effort to highlight the many girls, men, children and Taliban who were killed for the mistake of American drones. Ryder in her article narrates that the victim position of Malala is now arbitrarily used by war advocates. She quotes Al Jazeera and says, "She is now being used-rather, misused- in the West by portraying a wrong image of Pakistan as a violent and antiwomen society" (Ryder, 2015). Critics emphasised why all of a sudden Malala become the darling of western media? These discourses serve Malala as a passive object, waiting for Western rescue. The United Kingdom is constructed as a paternalistic, caring, benefactor, which always stands to help others. This discourse positions Pakistan as waiting for Western intervention. Rosie Walter quotes Lorraine Kelley's article in The Sun. Here she narrated that West is helping girls like Malala to live freely in peace. This is the reason why American troops should stay in Afghanistan. Journalists and politicians were in a race to spotlight the story of an innocent brown child who was shot by a brutal brown Muslim man for demanding education. So, now West has come to fulfill its responsibility as an angel to rescue her from these brutalities and has planted her in safe heaven called UK. (Walter, 2016) A racial narrative is being institutionalized beautifully here.
Yousafzai narrates when people narrated her story about "a girl shot by the Taliban"; she didn't feel it's a story about her at all (Yousafzai 301). Yousafzai declared that she did not "want to be thought of as the 'girl who was shot by the Taliban' but as the "girl who fought for education"" (Yousafzai 309). Although classified as a daughter of the West, Yousafzai self-identifies as "a proud daughter of Pakistan;" her decision to "not be like that" concerning customary Islamic and Pakistani traditions demonstrates her agency in self-characterisation. This new move was harming the previous activism of Malala, who was vocal and clear about her demand before the attack. She regularly wrote blogs for BBC Urdu. The Pakistani government opened a school in honour of her name. She also received Pakistan's first National Youth Peace Prize. She with her father was an active member in spreading awareness regarding the importance of girls' education. But after her attack, her story became the spicy news of rescue for the Western media and for critics she was just a passive object who fitted suitably to the reason of Western intervention in Third World country politics.

Nobody focused on how she gives herself an active role in her narrative and she also wants her audience to focus on her narrative only. She does not lose any opportunity to narrate her story. In her autobiography, she presents many possible ways of how she will resist if suddenly the Taliban attack her. She states "Like my father I've always been a daydreamer, and sometimes in lessons my mind would drift and I'd imagine that on the way home a terrorist might jump out and shoot me on those steps. I wondered what I would do. Maybe I'd take off my shoes and hit him, but then I'd think if I did that there would be no difference between me and a terrorist. It would be better to plead, 'OK, shoot me, but first listen to me. What you are doing is wrong. I'm not against you; I just want every girl to go to school'" (Yousafzai, 2013).

\section{DISCUSSION}

Malala does not defend the Taliban in her story rather she took an active role to understand the reason behind their brutality. That is why she narrates the whole history and rise of the Taliban. She also reflects on the international agencies that actively funded and participated in creating them. She elaborates how the Taliban were torn between the Pakistani army and the American army and their initial days. She contextualized how the national and international army creates a constant threat to the locals. She speaks out against the foreign army for helping and creating the Taliban passively. She cites a local information minister: "If we had not put guns in the hands of madrasa students at the behest of foreign powers, we 
would not be facing this bloodbath in the tribal areas and Swat" (Yousafzai, 2016). She accused American drones of killing innocents. She says both Taliban and Army are causing pain to their innocent valley. In this narrative, we encounter the narrative of a brown Muslim woman who was thought as a victim of Islam but she was capable enough to defend her position as an activist for the welfare of her country.

Malala is a believer in Islam and religion was one of the reasons that encouraged her for activism. But among most of the public narratives, this aspect remains invisible. This silence positions Malala as a passive participator of religion. On the other hand when the Taliban were projected, their main identity was portrayed from the point of view of religion. No one could bother to understand that the clash between Malala and the Taliban is not because of religion but because of Education, which Islam supports firmly. Little discourse was offered to understand Malala's criticism of the false presentation of Islam to fulfil their selfish motive. Not only the Taliban but also the Pakistani government could visualize the bright vision offered by Malala. Like Islamic feminists, Malala wished to separate the actual meaning of the Quran from a false interpretation of it. Malala accused the Taliban that they just focused upon the word meaning of the Quran but never bothered to understand its actual tone. She describes the madrassas of the Talibans worked as just manipulator of the mind of young boys. Taliban is nothing but an organisation that is in hunger of power. They just want to acquire power through the staircase of religion. The Radio Mullah says that the Quran instructs women only to stay in homes but Malala remembers that the first wife of Prophet (Peace be upon Him) Khadijah was a famous businesswoman. Now she could easily understand how the Taliban are contaminating the minds of the common people of Swat valley.

Malala was caught between her portrayal as a free-thinking woman by media and as a strong believer in the Quran. Malala finds the courage to fight against injustice in her religion. Malala's struggle is two-fold. Once she was victimised in the name of religion by the Taliban on the other hand she became a weapon for the western media to use to justify their intervention in Afghanistan and Pakistan. She is a believer and she believes herself as a correct interpreter of religious texts as she shows how the Taliban is manipulating them. In 2009, Malala wrote for the blog for BBC as pet name Gul Makai. As she explains in her memoir, Gul Makai is a heroine from a folk story in which a young couple from two different tribes falls in love. Unlike Romeo and Juliet, however, Gul Makai and Musa Khan do not die. Instead, "Gul Makai uses the Quran to teach her elders that war is bad and eventually they stop fighting and allow the lovers to unite" (Yousafzai, 2013) Malala followed Gul Makai, she always wanted to be a girl who would save her society from the trap of false representation of Islam. She challenged the religious authority by claiming that Islam does not have one monolithic interpretation that is given by the mullahs. Thus, Malala entered into a large battle; she not only raised her voice against the injustices that happened in her society but also challenged the weapons of Mullahs, who subjugate people in the name of religion. Like contemporary prominent Islamic feminists, Malala offered alternative readings of the Quran that are progressive regarding women's issues. She differentiated her idea of Islam from the Taliban's version: The terrorists were misusing the name of Islam and Pashtun society for their benefit. Pakistan is a peace-loving democratic country. Malala depicted the Taliban as uneducated and their edicts as ignorant of the Quran. She described the madrassas of the Taliban as places where young boys were indoctrinated by falsehoods. The Taliban were afraid of education, she repeated, because it is easier to control and manipulate people who cannot read or who don't know enough history or politics to question what they are told about Islam. Malala's misrepresentation easily caught the attention of the world; many claimed she "fails" to willingly adhere to Middle Eastern Islamic conventions such as purdah. But according to Malala, which Islam also supports, Purdah is not about veiling the face, Islam does not support face covering. Although accepted by the West because of her activism, Malala is ironically Othered by the West, too, because her religion has its origin in a Middle Eastern country, she is a devout Muslim, and, because she chooses to wear traditional head coverings. Many believed that the Taliban imposed veils upon Muslim women. Veiling is always a symbol of oppression but for many respectable upper-class women veil is tradition. They feel safe and confident in public with the veil.

Islamic feminism is an independent and individual interpretation of the Quran and the rights of women within the Muslim faith. Margot Badran's book Feminism in Islam: Secular and Religious Convergences, juxtaposed with secular feminism, Islamic feminism. She states that Muslim women have created secular and Islamic feminism. These two kinds of feminism apparently may look different but both of them are solving the crisis of Muslim women in multiple ways (Badran, 2013). Malala Yousafzai serves as an example of the multiplicity of Islamic feminism, as she does not fit the mould of purely one "feminist" ideology. Badran states that Islamic feminists look at the Quran to solve the problems they look at the Quran for the answer (Badran, 2013). Yousafzai, from a very young age, constantly argued with the lectures 
of Radio Mullah with her knowledge and understanding of Quran and Hadith- which had been exposed? She wanted to challenge many shared narratives about the capability of Women. Malala's questioning from women education to women's rights fit her to both Islamic and Secular feminisms. Interestedly, Malala also creates a bridge between Western Feminism and Islamic Feminism. The West has long argued with Islamic feminists about being 'Islam' and 'Feminism' are two oxymoronic terms. She argued how secular and Islamic feminism can work together for the betterment of the future.

In her New York speech to the U.N., where when she was 16, she wrote "her speech [not] only with the U.N. delegates in mind; [but also] for every person around the world who would make a difference" (Yousafzai, 2013). This incorporates the Muslim faith that follows within the lines of Islamic feminism in that "Islamic feminism rejects the notion of public-private dichotomy; it conceptualizes a holistic umma in which Quranic ideals are operative in all space" (Badran, 2013). She represents the "intersecting notions of gender equality and social justice and [an ability to] deconstruct patriarchy and disentangle it from Islam" as supported by scholars such as Amina Wadud (Badran, 2013). The notion that equality transcends a single religion, system, or person helps in illustrating how "feminism has been neither an exclusively Western construct nor monolithic," and that supporting equality is a universally important component of Malala's influence (Badran, 2013).

Islamophobia and sexism in western media is the result of dominant culturist interpretation and presentation of Islam. Many believed Islam is misrepresented because it may be a threat to western capitalist society and the stereotypes regarding Burqa or veil is the result of that bourgeois mindset. Another reason for misunderstanding Islam maybe because people confused religion with culture. Many cultural flaws are still in practised in Muslim countries which have nothing to do with religion but people believe them as part of Islam. Here the problem culminates. Malala Yousafzai is extremely strong and brave. She knows her rights and is also bold enough to fight for them despite knowing the power of her enemy. She is ready to sacrifice her life for the well-being of the world. She challenges the Western notion of Muslim women in every possible way. The reason behind this shared misconception regarding Islam and Muslims among media is the result of long culturalist assumptions about Muslim society. Media never come out of the perspective of cultural authorisation of Muslims. This view of Muslim society is creating chaos among Western feminists who try to understand the view of Islam on women. They never could comprehend the dynamic view of Islamic feminism and how Islamic Feminism is not a contrary organisation of Secular Feminism but a companion of it. Malala's story serves as resistance and a (rhetoric) expression of power. She rejected any false representation of her position. Though she took the Western media as a medium to circulate her message to the world she never lose control over her narrative, she remained firm and confident in her activism that she wanted education for every child across the world. Furthermore, she fit perfectly into emerging discourses of Islamic Feminism which believes in the potential survivor, who raises a voice against global injustices and creates a strong individual identity.

\section{CONCLUSION}

My paper has concentrated on the interplay of critical understanding of the global position of Malala Yousafzai and the influence of international media. I have tried to project here the story of Malala and the gradual shift of narrative. Malala was an activist since she was 11 years old, she used to write blog for BBC Urdu but nobody bothered to know her experiences under the Taliban regime until she was shot by two Taliban in her school bus. Here I have concentrated upon the moments when Malala was resistant but the media never highlighted those moments. In this portion, I have also verified the popular newspaper articles and interviews to argue my supposition. It will show how media can be a dangerous weapon to create false discourses. Then the final part of this chapter has examined Malala as an individual. This manifests how she is not only rejecting the patriarchal model of the religion of the Taliban but also the vulnerable image of third world women created by Western media. Here my main argument is how she is rejecting these images created by popular media and she is solely relying on her religion and correct interpretation of it. Therefore, my paper has projected my investigation in a systematic manner and has revealed new concepts and reoriented the research to another analysis phase. Each of these iterations has focused on interesting ideas, developed new ones, and finally redefined and enhanced different prototypes. Furthermore, this article will add a new dimension to the existing knowledge of this field and will help to create new perspectives in the domain of study for Muslim women narratives.

\section{ACKNOWLEDGEMENTS}

I would like to thank the Department of English of VisvaBharati, WB, India and my M.Phil course supervisor Professor Debarati Bandyopadhyay for her critical comments, constructive suggestions. Her dynamic vision, 
sincerity and motivation have helped me to carry on my research.

\section{REFERENCES}

[1] Badran, M. (2013). Feminism in Islam: Secular and religious convergences. Simon and Schuster.

[2] Baig, A. (2013). Malala Yousafzai and the white saviour complex. Huffington Post, 13.

[3] Mohanty, C. T. (1984). Under Western eyes: Feminist scholarship and colonial discourses. Boundary 2, 333-358.

[4] Moghadam, V. M. (2002). Islamic feminism and its discontents: Toward a resolution of the debate. Signs: Journal of Women in Culture and Society, 27(4), 1135-1171.

[5] Ryder, P. M. (2015). Beyond critique: Global activism and the case of malala yousafzai. Literacy in Composition Studies, 3(1), 175-187.

[6] Spivak, G. C. (2003). Can the subaltern speak?. Die Philosophin, 14(27), 42-58.

[7] Walters, R. (2016). 'Shot Pakistani girl': The limitations of girls education discourses in UK newspaper coverage of Malala Yousafzai. The British Journal of Politics and International Relations, 18(3), 650-670.

[8] Wadud, A. (1999). Qur'an and woman: Rereading the sacred text from a woman's perspective. Oxford University Press.

[9] Yousafzai, M. (2013). I am Malala: The girl who stood up for education and was shot by the Taliban. Little, Brown. 